\title{
気中単発放電における材料除去過程の観察
}

\author{
谷 貴幸*，辻田容希*，後藤啓光*，毛利尚武**
}

\section{Observation of Material Removal Process by Single Pulse Discharge in Air}

Takayuki TANI, Yoshiki TSUJITA, Hiromitsu GOTOH and Naotake MOHRI

\begin{abstract}
Although electrical discharge machining (EDM) can be used to perform high-precision machining, the material removal rate is low. From this viewpoint, it is extremely important to understand the process by which material is removed in the EDM method. In this study, the state of a workpiece being processed by a single pulse discharge was observed using a high-speed camera equipped with a high-magnification lens. To enable easy observation of the behavior of the material, a machining condition was selected in which there was a long duration of the pulse discharged by the needle electrode in air. Using a laser beam as illumination, an observation system employing a bandpass filter that allowed only a specific wavelength to pass through it was constructed. As a result, the behavior of the workpiece during the discharge could be observed without the effect of plasma emission. It was observed that several explosions intermittently occurred on the positive side of the workpiece during a single pulse discharge duration. Consequently, several small craters superposed in a narrow region were observed.
\end{abstract}

Key words : EDM, single pulse discharge, debris

\section{1. 緒 論}

放電加工法は，放電によって形成される微細な 放電痕の集積によって形状加工が行われる。この ことから，放電加工における加工特性を向上させ るためには，一発の放電による除去過程を正確に 把握する必要がある.

放電痕の形成プロセスとしては，従来から放電 による材料の溶融・蒸発，加工液の気化爆発によ る圧力の発生，発生した圧力による溶融金属の飛 散という考えが提唱されてきた ${ }^{1)}$. しかしながら, 測定機器の進歩に加え, 透明体材料を介した放電

* 筑波技術大学 (茨城県つくば市天久保 $4-3-15$ )

** 東京大学名誉教授 (東京都文京区本郷7-3-1)
現象の直接観察や新しいシミュレーション手法に よる解析などによって，提唱されてきた放電痕の 形成プロセスと実際の現象とは一致しない場合も あることが報告されている ${ }^{2,3)}$. 現象観察の有効 な手法として，ハイスピードカメラを用いた放電 現象の観察は既に行われているが ${ }^{4}$, 5)，放電中に 溶融金属が加工屃として排出されるタイミングや その飛散の詳細な様子は不明であり，一発の放電 中に具体的に溶融した金属がどのように除去され ているかは十分に観察されるに至っていない.

そこで本研究では, 極間の直接観察が比較的容 易である気中において, 数 $\mu \mathrm{s}$ 〜数百 $\mu \mathrm{s}$ 程度の パルス幅の単発放電によって生じる極間現象を八 


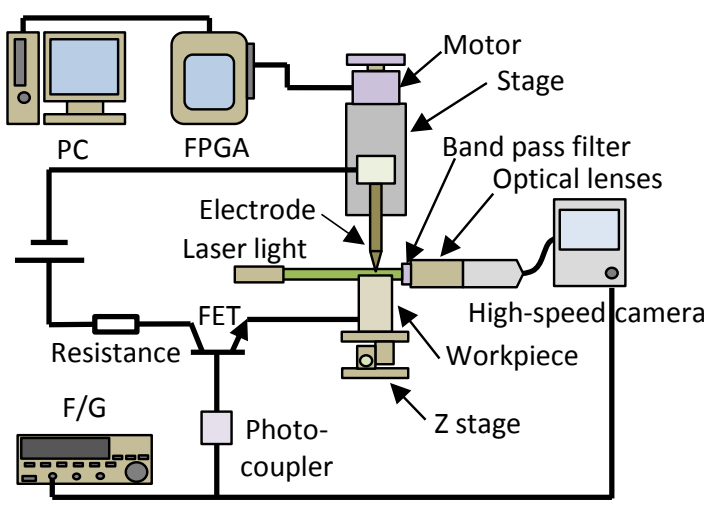

Fig .1 System for a single pulse discharge observation.

イスピードカメラにより観察し，一発の放電によ って材料が除去される過程を考察した．なお，極 めて狭い範囲で生じる溶融金属の挙動を観察する ために，ハイスピードカメラには高倍率でかつ長 いワーキングディスタンスを持つ観察系を構成し た.

\section{2. 実験装置}

\section{1 ハイスピードカメラによる観察}

本研究で使用する実験装置の概要を Fig .1 亿示 す. 加工形態は，気中において針電極対平面とし た. 針電極にはタングステン, 加工物には鋼材 ( S 50C）を用いた. 主な加工条件と撮影条件を Table 1, Table 2 にそれぞれ示す．撮影用のハイスピー ドカメラ (KEYENCE CO.Ltd, カメラ: VW-600M, モ ニター：VW-9000）には, 高倍率の光学レンズ

(KEYENCE CO. Ltd, VH-Z50L，倍率:500 倍, WD:85 $\mathrm{mm}$ ) を装着した.

Fig .2 (a) に構成した観察系により放電中の極間 を撮影した様子を示寸. 放電中の材料の挙動は, 放電による発光が生じるため, その様子は観察で きない，そこで，伊藤らによって開発された方法 により ${ }^{6)}$ ，放電中の材料挙動を観察した。 すなわ ち，特定の波長を持つレーザ光を照明光として， この波長のみを通過させるバンドパスフィルター を介した観察系を構築した。本実験では，波長 $532 \mathrm{~nm}$ の半導体レーザと中心波長 $532 \mathrm{~nm}$ ，半值幅 1. $0 \mathrm{~nm}$ のバンドパスフィルターの組み合わせによ り観察を行った.

この結果，Fig.2(b) に示寸ように，放電中であるに

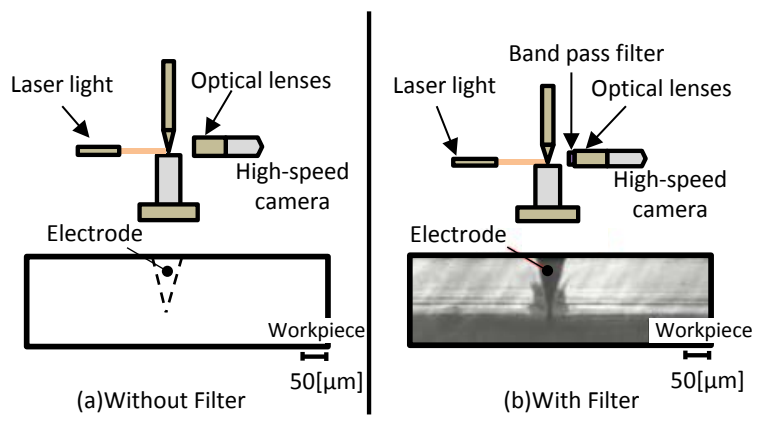

Fig .2 Observation of the gap during the discharge using a band pass filter.

も関わらず，発光の影響を受けず材料が飛散している 様子が観察された. この観察システムによって, 放電 中の溶融金属の挙動を観察することが可能となった。

\section{2 放電条件}

極間距離は，針電極と加工物との電気的な接触を基 準として，加工物側に設置したZステージを降下させ ることによって設定した. 本実験では, 気中での放電 を容易に行うために, 極間距離を $5 \mu \mathrm{m}$ に設定し, 電源 電土は $400 \mathrm{~V}$ とた. 電流制限抵抗を調整し, 放電電流 は23Aとした. 電圧を印加後に, FETに $100 \mu \mathrm{s}$ のパル ス信号を入力することによってパルス幅を設定した.

Table 1 Machining conditions

\begin{tabular}{|l|l|}
\hline Power supply voltage & $400[\mathrm{~V}]$ \\
\hline Current limiting resistance & $15[\Omega]$ \\
\hline Pulse duration & $100[\mu \mathrm{s}]$ \\
\hline Electrode polarity & negative \\
\hline
\end{tabular}

Table 2 Photographing conditions

\begin{tabular}{|l|l|}
\hline Exposure time & $1.11[\mu \mathrm{s}]$ \\
\hline Frame rate & $2.3 \times 10^{5}[\mathrm{fps}]$ \\
\hline $\begin{array}{l}\text { Image resolution } \\
\text { (pixel number) }\end{array}$ & $\begin{array}{l}160 \text { (horizontal) } \\
32 \text { (vertical) }\end{array}$ \\
\hline Magnification & 100 \\
\hline
\end{tabular}

\section{3. 放電中の陽極則溶融金属の挙動}

\section{1 加工屃の発生形態}

構築した観察システムにより, 放電中に溶融した材 料の挙動を観察した結果の一例を Fig.3に示寸. 図の中 央が実測した放電波形であり，その周囲に時間を追つ て特徽的な現象が現れたフレームを抜き出した結果を 


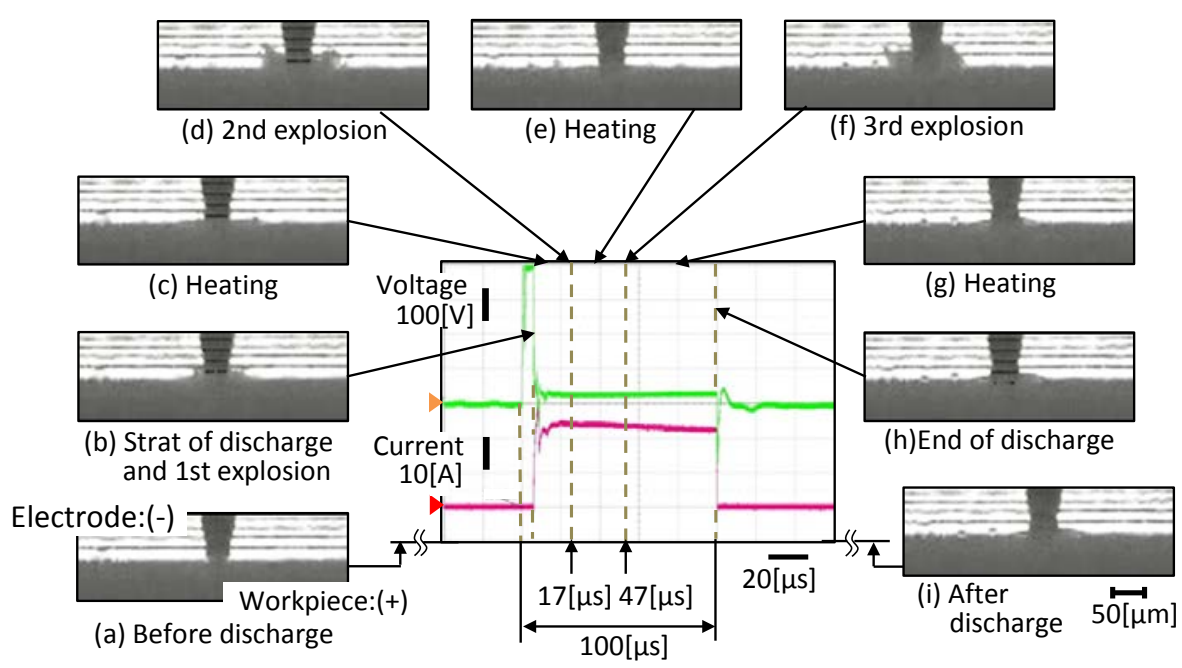

Fig .3 Gap phenomena observed during the discharge with its discharge waveform.

放電中に溶融した金属が加 工屑として飛散した回数お よびその発生時間について 検討した. 7 回の単発放電実 験を行い, 溶融金属の飛散が 発生した時間をまとめて Fig .4 に示す. $100 \mu \mathrm{s}$ の放 電パルス幅の条件において, 二回から四回の溶融金属の 飛散が確認された. すべての 結果において,一回目の材料 の飛散は, 放電の開始と同時 に発生した. 二回目の加工屑 の飛散は, $25 \mu \mathrm{s}$ 前後に多く 発生しており, 三回目以降の 飛散はさらに約 $50 \mu \mathrm{s}$ 後に発生する場合と発生しない 場合があった．放電開始から溶融した金属が飛散する 時間にバラツキはあるが，すべての実験において複数 回の飛散が確認された．なお，飛散回数が多い放電に おいては，撮影画面の左右に偏って溶融金属が飛散す る傾向を示した.

以上，本実験の条件においては，一発の放電中に一 定時間をおいて陽極側では複数回の材料の除去が爆発 的に生じることが観察された。陽極側では一発の放電 において生じる材料の除去は一回であると考えられて きたが，その考えとは異なる場合があることが示され た.

\section{2 短パルス放電における溶融金属の挙動および放電 痕形態}

前述した溶融金属の飛散の発生タイミングの測定結 果から, 数 $\mu \mathrm{s}$ 程度の短いパルス幅では, その飛散は 一回となると予想される. パルス幅が $9 \mu \mathrm{s}$ の条件にお いて撮影された極間の様子をFig .5に示寸．同図には， パルス制御信号およひ撮影開始から $4.3 \mu \mathrm{s}$ 毎の撮影 結果をすべて示している.

この時の放電庠孔時間は, $3 \mu \mathrm{s}$ 程度であり, 最初の フレームには放電の開始前と比べ変化が無かったため, まだ放電は発生していない状態である．2フレームに おいて，放電の発生とともに周囲に盛り上がりが生じ ている. その後のフレームにおいて，溶融した金属の 飛散あるいは盛り上がりが成長している様子が観察さ れた. パルス幅を短く設定した場合には，観察された 


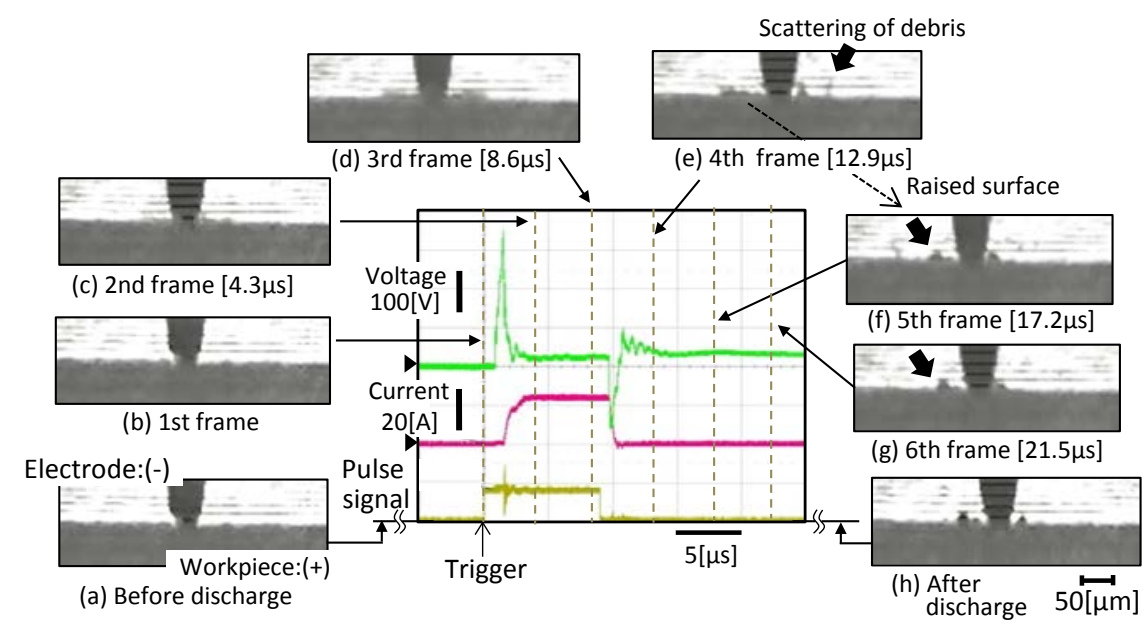

Fig .5 Gap phenomena observed under the short pulse duration with its discharge waveform

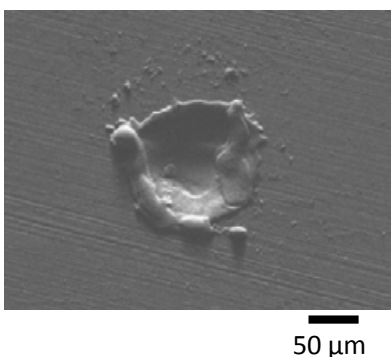

(a) Pulse duration $8 \mu \mathrm{s}$

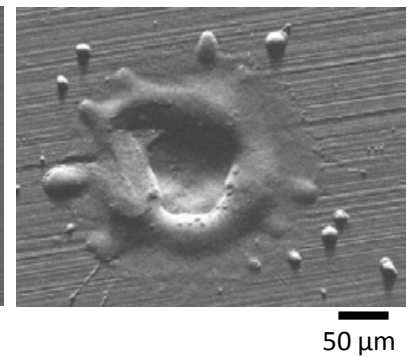

(b) Pulse duration $100 \mu \mathrm{s}$
Fig .6 Photograph of a single pulse discharge crater.

溶融金属の飛散回数は一回となった. この時に成形さ れた放電痕をFig .6 (a) に示寸. なお, Fig .6 (b) には $100 \mu \mathrm{s}$ のパルス幅で二回の飛散が観察された放電痕 も示している. 一回の加工屑の飛散であったパルス幅 の短、 条件での放電痕は，比較的綺麗な円形となって おり，爆発的な除去が一回のみであった様子がうかが える.これに対して，二回の爆発的な除去が観察され た場合には，中心部には図(a) と同様な除去が発生し， その後さらに二回目の懪発によってさらに除去領域が 広がり，周囲に盛り上がりも観察される．撮影された 爆発的な溶融金属の飛散回数に対応した放電痕が形成 されていることから，本実験の撮影結果は極間の様子 をかなり正確に現わしていると思われる.

パルス幅の短い放電における現象を詳細に観察する と，放電終了後も溶融金属力桬䊦して飛散しているこ とが明らかとなった. Fig. 5 (d) に示す3フレーム直後 においてすでに放電が終了しているにもかかわらず, その後も図中の矢印で示寸ように溶融金属の飛散や盛 り上がりが進行している様子が撮影された。 このこと
から, 放電によって材料が溶 融状態にまで達した場合に は, その後放電が停止しても, 溶融金属が加工而となって 排出されるまでの駆動力は 維持されると考えられる. ま た，この現象は, 繰り返し放 電において放電の位置が移 動した後でも, その前の放電 によって短絡に至ることや 休止時間中に生じる橋絡 7) などとも共通した現象と考 えられる. 極間の電気信号の みでは捉えられないこれら の挙動は，放電加工にける極間制御の困難さの一因に なっていると考えられる.

以上の結果から，短いパルス幅の条件では，溶融金 属の飛散回数は一回であり, パルス幅が長くなれば, その飛散回数が増えるといえる. また，放電が終了し た後にも，溶融金属の飛散や盛り上がりの発生などが 継続することが直接観察された。

\section{4. 極性による加工屃発生形態の違い}

これまでは，陽極側での材料の除去の様子を観察し てきた．本章では，陰極側での溶融金属の挙動につい て検討する，陰極点におけるアーク柱の挙動は，電流 密度の高い点が不規則に移動していることが観察され ており ${ }^{2)}$,これまでこ観察した陽極側での現象とは異な ると推則される.

被加工物を陰極として，これまでと同じ電気条件に より，単発放電による極間の観察を行ったが，溶融金 属が加工屑として飛散する様子は見られず, 電流值を $50 \mathrm{~A}$ と高くした場合でも同様に観察することは出来な かった，そこで，材料の除去量が多く，溶融金属の挙 動が観察されやすいと予想される融点の低い西鉛合金 を被加工物として，電流值を 30A に設定して単発放電 実験を行った。

$100 \mu \mathrm{s}$ のパルス幅の放電において，放電発生から $21.5 \mu \mathrm{s}$ までの極間の様子および放電の途中である $64.5 \mu \mathrm{s} \sim 81.7 \mu \mathrm{s}$ について $4.3 \mu \mathrm{s}$ 毎に抜き出した 撮影結果をFig.7 に示す. 被加工物を亜鉛合金とするこ とによって，放電中に陰極において材料表面が動く様 


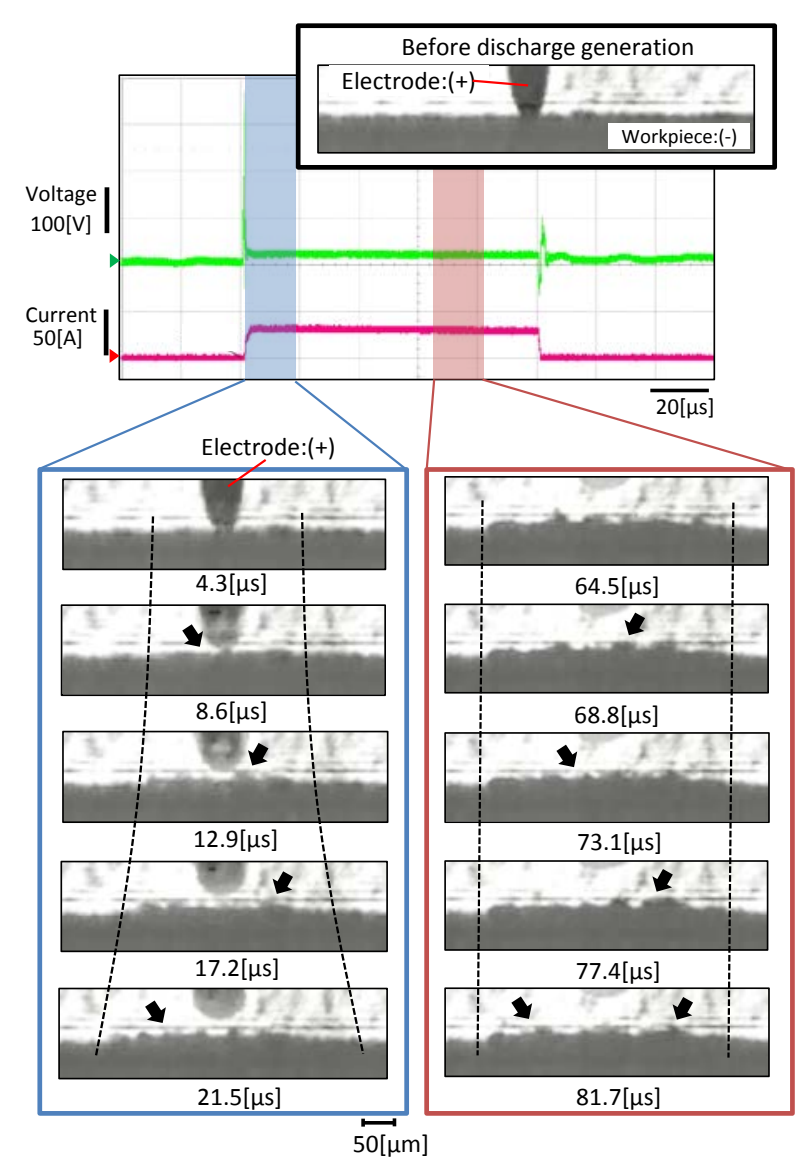

Fig .7 Gap phenomena observed under the condition of workpiece (-) with waveform.

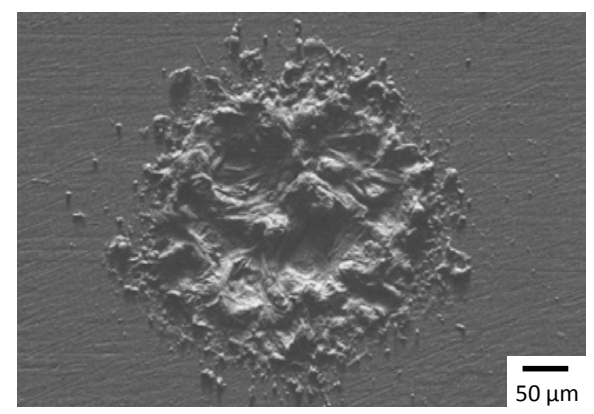

Fig .8 SEM image of a single discharge crater (Electrode polarity: $(+)$ ).

子を観察することができた. 各フレームにおいて，溶 融金属の飛散あるいは盛り上がりが出現したと思われ る箇所を矢印により示している．陽極て観察された現 象とは異なり，新しい溶融金属の飛散あるいは盛り上 がりが間を置かずに次々と生起している様子が観察さ れた.この現象は，パルス幅全体に渡って継続した。 また，図中の点線で示寸ように，陰極則の飛散領域は， 放電開始とともに拡がりを見せ，定常拡がりに落ち着 く．陽極側の金十電極は，放電中に時間の経過とともに 消耗していく様子も観察され，陰極とした場合と比較
して大きく消耗した.

この放電によって，形成された放電痕のS EM像を Fig.8に示寸. 全体として円形の放電痕か形成されてい るが，放電痕表面を詳細に観察すると細かく何度も材 料が除去されたような跡が観察された。これは，電流 密度の高い点が表面を不規則に移動した結果であると 考えられる.

以上の観察結果から，陽極側と陰極側では，材料の 除去過程は大きく異なることが明らかとなった．陽極 側では，放電点の移動はほとんど無く，放電中に表面 への加熱が継続され，これに伴って次章で考察する溶 融金属の複数回の爆発的な除去が発生したと考えられ る. これに対して, 陰極側では, 電流密度の高い点が 激しく動き回っているために，その材料除去のほとん どは蒸発に伴う飛散であると考えられる.

\section{5. 除去メカニズムの推定}

以上の観察により得られた結果から，一発の放電に よって，陽極側およひ陰極側において材料の除去が生 じるメカニズムを考察する. 推定したモデルを Fig .9 に示す.

陽極における最初の溶融金属の飛散は，入熱密度が 非常に高く, 最表面は僢時に繁発状態となり，これに よって溶融金属の盛り上がりあるいは飛散が生じる. その後, アーク柱は膨長によって入熱密度は低下寸る が，表面一の加熱は継続され，伝導熱により内部に溶 融域ができる. 表面の蒸気圧がある限界を超えると， 表面蒸発による反跳力 $\left.{ }^{8}\right)$ が生じ, 溶融した内部の金属 が吹き飛ばされる. 反跳力によって溶融金属が飛散し た後は, 新しく出現した面が再び氻熱されることにな る. なお，表面加熱によって沸点に達する時間は，放 電点の電流密度 (加熱流密度) と沸騰替熱および弗点 と加熱開始時点での温度差などが効いてくる.

このようなプロセスが放電中に繰り返し発生す るため, 一発の放電中に複数回の材料の除去が行 われたと考えられる. なお，陰極については，電流 密度の高い放電点が表面を不規則に移動したため，陽 極における1回目の除去プロセスが放電中に繰り返し 生じたと考えられる.このように，陰極側における除 去プロセスは蒸発が主体であるが，陽極側では蒸発に 加え溶融金属を加工屑として排出している. この除去 プロセスの違いが，極性による加工効率の違いの原因 


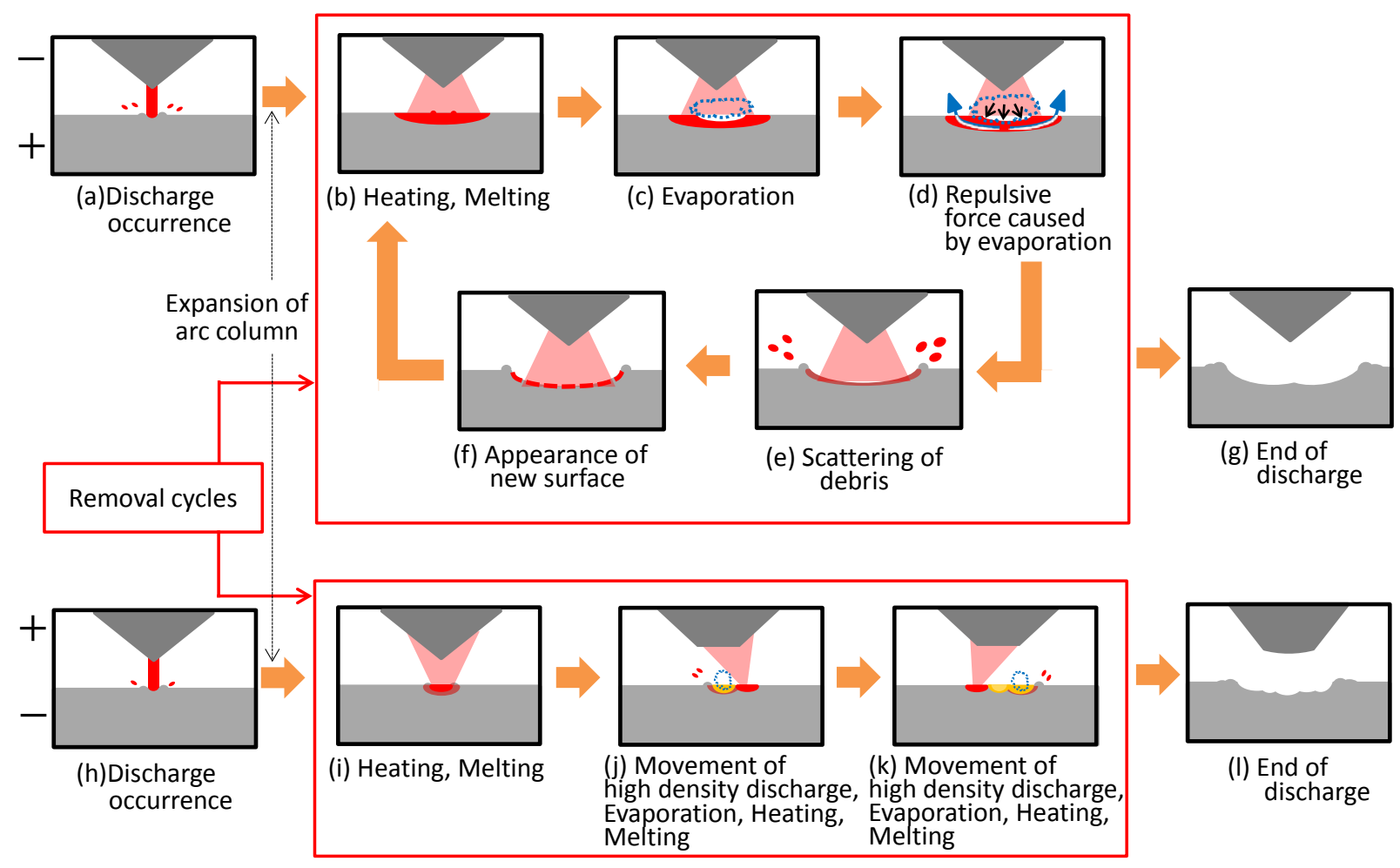

Fig .9 Model of the material removal mechanism.

の一つとも考えられる.

本論文では，気中放電加工における溶融金属の飛散 の観察から陽極及ひ陰極側での材料除去プロセスを考 察した. 実際の放電加工法は, 加工液中で実施される ことから，より現実に即した材料除去プロセスを把握 するためには，更に様々な加工環境での観察，測定等 を行う必要がある。

\section{6. 結 論}

単発放電中の溶融金属を観察できるシステムを構築 し, その材料挙動から放電による材料の除去メカニズ 厶を考察した。 得られた結果を以下にまとめる.

(1)数十 $\mu \mathrm{s}$ を超えるパルス幅の放電においては, 一発 の放電によって行われる陽極側の材料の除去は一 回ではなく，複数回であった。

（2）放電によって，一旦蒸発，溶融犬態にまで達した場 合には，その時点において放電が終了しても溶融金 属の飛散あるいは盛り上がりの成長が生じること が改めて確認された。

（3）陰極においては，放電中は連続的に溶融金属の飛散 あるいは盛り上がりが生じる. 陽極における初期の 状態が放電パルス中に継続して行われるため, 陰極
側は蒸発を中心とした除去が主体となる.

（4）陽極において一発の放電中に複数回の除去が生じ る理由は, 放電による材料表面の加熱 蒸発を伴う 材料の飛散，材料の飛散による新しい面の出現，再 加熱のサイクルを繰り返すためと考えられる.

\section{謝 辞}

本研究の一部には, 科学研究費補助金 (基盤研究(C) 16K06794）を用いました，記して感謝致します。

\section{参考文献}

1) 齋藤長男: 放電加工のしくみと 100\%活用法, 技術語論社, (1979)p.17.

2) 北村朋生，国枝正典: 透明体電極を用いた放電加工極間現 象の直接観察, 精密工学会誌, Vol.81, No.11 (2015) pp.983-986.

3）㛫尭冬，韓笑，国枝正典: 分子動力学を用いた放電加士の 除去メカニズムの解明，電気加工技術，Vol.37， No.116 (2013) pp.25-37.

4) 草深友佑, 早川伸哉, 糸魚川文広, 中村隆 : 放電加工の放 電点における溶融金属除去の直接観察，電気加工学会全国 大会（2013）講演論文集，pp.3-6.

5) 小島彰, 国枝正典:放電加工におけるアーク柱の膨涱速度, 2006 年度精密工学会秋季大会学術講演会講演論文集, 


\section{pp.671-672}

6) 田辺里枝, 伊藤義郎, 毛利尚武: 大電流単発放電における 微細車帆形成現象の時間分解観察とその形成ダイナミクス, 精密工学会誌，Vol.73, No.6(2007)pp.682-687.

7) 齋藤長男, 毛利尚武, 大竹 定: 放電加工の消イオン特性 (第 1 報)，昭和 62 年度精密工学会秋季大会学術講演会論 文集 (1987) pp. 713-714.

8) 野口暁，大村悦二，平田好則：レーザの多重反射と蒸発を 考慮したレーザ穴あけ加工の熱流体解析一第2 報，レーザ の多重反射と材料の蒸発を考慮したレーザ穴あけシミュレ ーションー，レーザ加工学会誌，Vol.14, No.2 (2007) pp.113119.

（2017年10月 10日受付） 